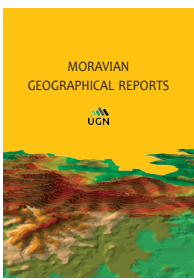

MORAVIAN GEOGRAPHICAL REPORTS

The Czech Academy of Sciences, Institute of Geonics

journal homepage: http://www.geonika.cz/mgr.html

doi: https://oi.org/10.2478/mgr-2021-0016

\title{
Peripheral areas and their distinctive characteristics: The case of Hungary
}

\author{
János PÉNZES a *, Gábor DEMETER ${ }^{b}$
}

\begin{abstract}
The delimitation and classification of peripheral settlements using multivariate statistical methods is presented in this article, with a case study of Hungary. A combination of four different methods provided the basis for the delimitation of settlements defined as peripheral. As significant overlapping was detected between the results of the different methods, peripheries - more than one-fifth of the Hungarian settlements - were identified in a common set of the results. The independence of the results from the applied methods points to the fact that peripherisation is multi-faceted, and the peripheries of Hungary are stable and well-discernible from other regions. After the identification of peripheral areas, we classified these settlements into groups based on their specific features. Multiple steps specifying the relevant variables resulted in selecting the most appropriate 10 indicators and these served as the basis for a hierarchical cluster analysis, through which 7 clusters (types of peripheries) were identified. Five of them comprised enough cases to detect the most important dimensions and specific features of the backwardness of these groups. These clusters demonstrated a spatial pattern and their socioeconomic and infrastructural features highlighted considerable disparities. These differences should be taken into consideration when development policies are applied at regional levels or below.
\end{abstract}

Keywords: core-periphery dichotomy, demographic processes, multivariate statistical methods, peripheral areas, peripherisation, regional development planning

Article history: Received 18 August 2020, Accepted 24 April 2021, Published 30 September 2021

\section{Introduction}

The term 'periphery' is not a clearly defined term but has numerous interpretations from spatial to sociodevelopmental perspectives. As a consequence, the delimitation of peripheral areas might be based on different methods and several indicators supposed to illustrate development levels. In the case of Hungary, during the last few decades numerous methods were tested and used to identify the spatial structure of developed and peripheral (backward) areas. In the current analysis a new attempt is made to delimit the most backward regions at the settlement level (covering the LAU 2 units) within Hungary after 2010 compared to former experiences.

One of the most important issues relating to this study is how to categorise the most backward and peripheral settlements (often a synonym for backwardness in Hungarian discourse). This task was assigned to regional planning entities through different intervention policies, including social, educational and employment policies. Multivariate statistical methods might provide an appropriate tool for the categorisation of peripheral settlements. But another important methodological issue is the selection of the most relevant statistical data that describe the features of development and the dimensions of spatial social inequalities. Thus, the current paper aims to find the appropriate indicators for a multivariate statistical analysis, through which the most peripheral settlements of Hungary can be identified and separated from one another based on their characteristics and specific features.

\section{Theoretical background}

\subsection{The concept of a core-periphery relation and the types of peripheries}

The concept of core-periphery relations is based largely on an explanation of uneven capitalist development (Hirschman, 1958) that causes divergence in the development of regions regarding their economic position and the level of concentration of resources and capital (Williamson, 1965). The approaches and theoretical backgrounds have changed

\footnotetext{
${ }^{a}$ University of Debrecen, Department of Social Geography and Regional Development Planning, Debrecen, Hungary (*corresponding author: J. Pénzes, e-mail: penzes.janos@science.unideb.hu)

${ }^{\mathrm{b}}$ Institute of History, Research Centre for the Humanities, Eötvös Loránd Research Network, Budapest, Hungary
} 
during the last decades. The objectives of the core-periphery models have been determined, on the one hand, by research on the transformation of societies and production modes, and on the other by the effects of these changes on given areas at different territorial levels (Ramírez, 2009). The core-periphery relations tend to be analysed not only with scalar datasets but increasingly within networks (Borgatti and Everett, 1999) and with vector data (Erlebach et al. 2019). Peripheral positions might appear in global, national and regional contexts and in local structural relations, with interlinkages among them (Kreckel, 2004; Kühn, 2014; Erlebach et al., 2019) representing a fractallike pattern (Halás, 2014; Erlebach et al., 2019).

In the social sciences, the core-periphery dichotomy is regarded as a basic paradigm, but its dual meaning was clarified by Immanuel Wallerstein, who extended this bipolar concept by introducing the definition of 'semiperiphery' (Wallerstein, 1976). The terms and concepts of core and periphery are regarded as inter-relational, interdependent and derived from each other (Kühn, 2014). Cores are characterised by proactive measures, semi-peripheries are dominated by successful adaptive models, while a periphery is usually dominated by reactive (and often unsuccessful) measures - thus the interdependence turns into an asymmetric relation. Due to this close relation, it is difficult to create a reliable overall definition for core and periphery, both conceptually and empirically (Bernt and Colini, 2013).

Thus, the diverse meaning and content of peripherality can be perceived rather through categorisations. Reynaud separated four kinds of peripheries (dominated; abandoned; integrated and exploited; integrated and annexed), and two types of centres (dominant and hypertrophic) (Reynaud, 1981). Certain territories do not fit this dichotomy: isolated (isolate) and blind-spot (angle mort) regions can therefore be classified as marginal areas (Leimgruber, 2007). As part of the discussion about geographical marginality, four types of regions were proposed: geometric, ecological, economic and social (Leimgruber, 1994). Nemes-Nagy identified three approaches to the core-periphery relationship, separating locational (geographical), economic (level of development-related) and social (political powerrelated) approaches (Nemes-Nagy, 1996). Novotný and colleagues created the following subgroups after the analysis and synthesis of individual authors' approaches to peripherality and marginality: geometric, political, ecological, economic and social (Novotný et al., 2015).

The Hungarian scientific discourse and regional policy tend to primarily focus on two aspects in connection with peripherality: peripheral locations with disadvantageous transport accessibility (e.g. Tóth, 2006, Lőcsei and Szalkai, 2008; Kiss, 2012) and areas that are socially and economically underdeveloped (Nagy et al., 2012). These aspects interrelate with each other in the case of Hungary, causing socioeconomic problems aggravated by the risk of transport-related exclusion (Tagai et al., 2018).

The delimitation of peripheral areas is, therefore, generally considered along with multiple indicators and different methods. The multidimensional character of peripherality satisfies the demand for generalising instead of using a specific category (Halás, 2008). In spite of their multidimensional character, most geographical studies arguably focus on static descriptions, instead of investigating the process of peripheralization (Kühn, 2014; Lang, 2015).

\subsection{Delimitation methodologies of peripheral areas in East-Central Europe}

Because of their multidimensional character, peripheral areas are difficult to delimit by universally accepted methodologies. The various features of spatial development lead to diverse procedures to demarcate these areas in each country. Significant changes could be discerned in the methodology during the last few decades, especially in indicators due to changing socioeconomic conditions, rapidly developing statistical databases and the evolving approaches of stakeholders. Nonetheless, almost all approaches have some relation to the ground-breaking work of Berry (1964) at the outset of the Quantitative Revolution in Geography.

During the socialist era, the study of economic and infrastructural indicators was common (e.g. Beluszky, 1976; Potrykowska, 1985). At the same time, demographic variables were also included in the development studies, emphasising the direct relation between economic prosperity and the dynamic growth in population numbers (e.g. Gawryszewski and Potrykowska, 1988; G. Fekete, 1991).

The transformations of political regimes and the collapse of socialist socioeconomic structures caused a rapid increase in the importance (and numbers) of indicators describing the rising structural crisis (e.g. unemployment or industrial sector) in transitional Central European countries (Dövényi, 2001; Kovács, 2004). The proliferation of innovations that resulted from the transition to market economies has also received greater attention in the postsocialist countries (Rechnitzer, 1993). The widening territorial statistical background and the rapid increase in the possibilities for analysis caused a boom in the application of different methodologies and in the number and variety of socioeconomic and infrastructural indicators derived from the investigation of the spatial structure. After 2010, the revaluation of natural and environmental components could be detected, primarily as the result of the increasing role of sustainable development concepts (e.g. Nagy and Koós, 2014; Papp et al., 2017; Bański et al., 2018).

\subsection{Altered spatial patterns in Eastern Central Europe and in Hungary after the transition}

Now that the socioeconomic spatial structures have been transformed in East-Central Europe after the political transition to capitalism, similar spatial characteristics and dichotomies can be detected mainly in the countries that form the Visegrád Group (Sokol, 2001; Komornicki and Czapiewski, 2006; Pénzes, 2013b; Novotný et al., 2015). Thus, regional inequalities significantly increased during the early 1990 s as a direct consequence of the transition from a centrally planned state economy to the privatised market economy (Nemes-Nagy, 2006), and the spatial pattern became even more polarised (Nemes-Nagy, 2000; Szabó, 2003; Havlíček et al., 2005). The capital-labour relationship has become the main driver behind iniquitous, uneven capitalist development (Timár, 2007).

The sudden and profound transitional changes significantly affected the occurrence and economic situation of peripheral areas. The rest of the traditionally backward areas had to face deepening socioeconomic problems. Rural areas were victimised by the unsuccessful transformation of the ownership and production structure of agriculture (Csatári and Farkas, 2008), along with the significant degradation of the market framed by the Council for 
Mutual An increasing spatial concentration of peripheral areas became visible in the eastern regions of the Visegrád countries (e.g. Gorzelak, 1996).

At the same time, some parts of the peripheral settlements began to develop due to favourable socioeconomic conditions, especially at the Western border which became trespass able again and in the vicinity of the largest towns (Heidenreich, 2003; Halás and Hurbánek, 2008; Egri and Köszegi, 2018). Suburbanisation became one of the most important processes determining internal migration in the countries of Eastern Central Europe, especially in the areas surrounding the capital cities and larger towns (Kovács, 2004). This development has had a significant effect on the development path of the attached settlements.

The positive impact of polycentric spatial development concepts (Copus, 2001) on the mitigation of intra-regional disparities is debated (Malý, 2016; Mulíček and Malý, 2019). In Hungary, functional regions are dominated by Budapest and its metropolitan region (Sütö, 2008; Pénzes and Pálóczi, 2017; Szabó et al., 2014). The outstanding position and concentrated economic performance of the largest towns is strengthened by the transport network, with Budapest at its centre (Egri and Kőszegi, 2020). Moderate and decreasing intra-regional inequalities could be observed in the intensive commuting zones of Hungary's developed regions, while small and medium sized towns as centres of employment in the backward regions (Sütö, 2008) showed island-like development patterns and weak commuting relations, resulting in high within-region disparities even after the millennium (Pénzes, 2013a).

\subsection{Peripheries in Hungary before and after the political transition}

Peripheral areas in Hungary are characterised by 'traditional' peripherality, and some authors claim that the roots of Central European backwardness could be traced back to the Middle Ages, as compared to Western Europe (Baranyi, 2004). Disadvantageous natural conditions significantly influenced the development possibilities of settlements and resulted in the conservation of outdated types of social formations and cultivation methods during the $18^{\text {th }}$ century. Disadvantageous social-demographic traditions might have also contributed to the step backward for these Central European countries (e.g. in the case of the Ormánság territory along the River Dráva in southwestern Hungary). The failure of some territories to reap the benefits of the general economic boom during the last decades of the $19^{\text {th }}$ century deepened the marginalisation of the peripheral areas. The construction of railway lines generated new geographical peripheries being at a disadvantage, as they were situated far from the main lines. In other words, underdeveloped areas started to form with expressively unfavourable socioeconomic indicators even before the Trianon Peace Treaty (breaking up the geographical makeup and economic structure of Hungary at the time), whereas the latter also had deep, unfavourable impacts on the present borderlands of the country (Demeter, 2018; 2020; Szilágyi, 2019; Pénzes, 2020). The new borders deepened the previously existing problems while generating new ones. Urban hinterlands were separated from the urban centres by the new border - primarily in the case of north-eastern, eastern and southern Hungary (Süli-Zakar, 1992). These backward areas were not only observable in the interwar period (Szilágyi, 2020), but some have persisted even up to the present. Beside these, the territorial changes after Trianon determined the enormous strengthening of Budapest within the spatial pattern, one that can be regarded as monocentric notwithstanding the attempts of the regional policy in the $20^{\text {th }}$ century.

During the socialist era, new inequalities were generated by the construction of socialist industrial towns, centrally controlled redistribution, an exaggerated support of industrialisation and the forced transformation of agricultural ownership. The (re)distribution of developmental resources was in complete accord with the settlement hierarchy through the system of settlement councils (Perczel-Gerle, 1966). In this respect, small settlements were at the end of the chain of redistribution, and their access to resources was strictly limited or even impossible. The National Settlement Network Development Framework Plan of 1971 made this situation even more difficult. Public services and infrastructural elements began to vanish in the smaller villages only to reappear in the cities as the result of the concentration of financial resources in large metropolises (Beluszky, 1979).

The scientific investigation of peripheral (i.e. 'unfavourable') settlements was initiated during the mid1970s (Beluszky, 1976). This research analysed the spatial disparities in living conditions with special attention to the infrastructural and institutional supply and accessibility.

The first official action plan by the Hungarian Cabinet to develop the most unfavourable (according to their economic situation) settlements as part of the Hungarian regional policy's first major developmental attempts started in 1986 (Tomcsányi, 1986); however, the political transition to capitalism aborted these efforts. The transformation crisis - generating territorial inequalities too - urged for interventions by Hungarian regional policy and prompted the regularly updated delineations of the supported (most backward) settlements (these delimitations were accomplished by the Hungarian Central Statistical Office HCSO). The goal behind the delimitation of backward settlements was to allocate the developmental resources for the most deprived territories and settlements appropriately (however, the effectiveness of these attempts is disputed - see Nagy, 2009). Hungarian researchers and scientific institutes developed numerous methods with different approaches: for instance, focusing on the spatial capital, territorial deprivation and human development in order to outline the spatial developmental pattern of Hungary (for a summary, see Pénzes, 2015).

This research brought attention to the rapid rise in unemployment and a quickly developing structural crisis in the heavy industrial and coal mining areas (e.g. in the surrounding areas of Salgótarján, Ózd, Kazincbarcika, Edelény in north-eastern Hungary, and Komló, Sásd in South Hungary). Besides these locations, the towns of Ajka, Oroszlány, Várpalota (in north-western Hungary) also had to face a significant decline in their local industrial economies. The latter territories, however, could restructure their economy or - through commuting - profit from direct foreign investments targetting the nearest larger towns.

The transitional crisis areas are located near the traditional backward areas in north-eastern and southwestern Hungary (Kovács and Koós, 2018). As the result of this, extended peripheral areas were formed after the political transition (the current state of which is described below). At the same time, the status of the former peripheries in western and north-western Hungary consisting of typically small 
villages, began to thrive due to the rapid growth of the region accelerated by direct foreign investments (mainly in the automotive and electronic industry and their related supplier chains) (Molnár et al., 2020) and - especially after 2010 - due to cross-border commuting to Austria (Kiss and Szalkai, 2014; Egedy, 2017).

Regional inequalities - as demonstrated by taxable income, for example - have typically decreased in the post-millennium age in Hungary (Pénzes et al., 2014), but the process of peripheralisation may even take place within these stagnating or decreasing spatial disparities (Šimon, 2017). As a result of the above briefly summarised processes, it is highly possible that peripheral settlements may differ from each other in their characteristics - not only regarding their geographical location but also their socioeconomic indicators. Using multivariate statistical methods, we attempt to identify these groups and their distinctive features (e.g. Bernard and Šimon, 2017; Bański et al., 2018).

\section{Data and methods}

In the current study, four different methods are applied in order to create a more comprehensive and complex methodology to identify peripheral settlements (LAU2 territorial level) after 2010. The selected methods are all appropriate for the study of territorial development and peripherality to certain extent, but all have different characteristics and focus. The described methods refer to the same LAU2 territorial level (3,155 settlements in Hungary), for this reason the modifiable area unit problem (MAUP) is not significant as these researches are based on the most detailed territorial data publically available. The research thus cannot deal with the local level within-settlement territorial segregation.

1. The index of territorial deprivation was adapted to the Hungarian circumstances by the Institute for Regional Studies (IRS) of the Hungarian Academy of Sciences. The multidimensional territorial deprivation index gives a reliable long-term overview about spatial social processes based on census years through seven variables (Kovács, 2010; Koós, 2015).

2. The Hungarian index of objective well-being (the formula of this index was also developed by the IRS) reflect most of the proposals in the Stieglitz-Sen-Fitoussi Report (Stieglitz et al., 2009). This method provides an exceptionally complex and sensitive indicator thanks to its 'holistic' view. The Hungarian objective well-being index contained 30 indicators categorised into 10 groups (see Nagy and Koós, 2014). The results of objective wellbeing were also included in the investigation because of its international importance.

3. The HCSO developed the recent delimitation of the favoured settlements of the regional policy on the basis of socioeconomic and infrastructural development (altogether 24 indicators were applied). The 1,054 settlements (one third of the Hungarian settlements) with the lowest development values were classified as disadvantageous (105/2015 [23 ${ }^{\text {rd }}$ April] governmental decree). This methodology was also regarded as essential to become part of our comprehensive analysis of peripheral settlements. The computations were repeated by the authors.

4. Finally, the fourth complex indicator was created in order to provide a methodologically reliable way to facilitate delimitation of peripheral settlements. The components of the complex indicator known as "territorial development index" were selected from 136 various social, demographic, economic and infrastructural indicators with the help of a multistep and accurate narrowing process which resulted 7 indicators (Pénzes, 2015, 2020). This method provided the basis for investigating the Hungarian spatial pattern and the location of peripheral areas below (Fig. 1 - discussed later).

All of the briefly demonstrated methods are appropriate for sorting the settlements according to development level. After computing the results, a comparison was made with the help of a correlation matrix using Pearson-coefficient (multivariate calculations were accomplished with the IBM SPSS 24.0). The objective of this analysis was to detect the statistical relationship among the different methods (Tab. 1).

The groups of peripheral settlements were delineated by using the threshold of the recent governmental document (105/2015 [23 ${ }^{\text {rd }}$ April] governmental decree), which meant the delimitation of 1,054 locations with the lowest development values. The overlapping of the results of the four mentioned different methods was also investigated (Fig. 2), and the results of this comparison (the common set of the four methods) provided the basis for the delimitation of the confirmed peripheral settlements investigated

\begin{tabular}{|c|c|c|c|c|}
\hline & 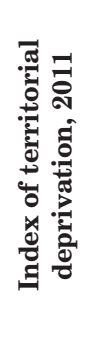 & 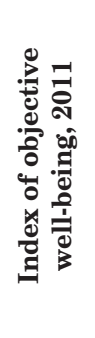 & 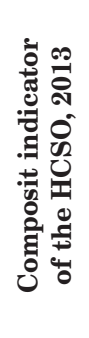 & 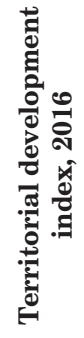 \\
\hline Index of territorial deprivation, 2011 & 1.000 & 0.860 & 0.859 & 0.847 \\
\hline Index of objective well-being, 2011 & 0.860 & 1.000 & 0.895 & 0.820 \\
\hline Composit indicator of the HCSO, 2013 & 0.859 & 0.895 & 1.000 & 0.831 \\
\hline Territorial development index, 2016 & 0.847 & 0.820 & 0.831 & 1.000 \\
\hline
\end{tabular}

Tab. 1: Correlation matrix of the investigated complex development indicators Sources: author's computations based on the datasets from Hungarian Central Statistical Office and TeIR; Koós, 2015; Nagy and Koós, 2014; 105/2015 (23 ${ }^{\text {rd }}$ April) governmental decree of the Hungarian Government 
in this study. This group of settlements was analysed below by multivariate methods in order to discover their characteristics and to classify them.

For this set of settlements altogether a total of 53 different demographic, socioeconomic, and infrastructural indicators were collected on the LAU2 settlement level (from 2016 and the 2011 census), and normality tests were computed to select those indicators appropriate for further multivariate analyses. A total of 36 indicators showed normal distribution (some of them only after logarithmic transformation).

The Principal Component Analysis (PCA) was applied (using the Varimax rotation) to discover the relationship of the selected indicators. The computed 7 components explained the $81.1 \%$ of the total variance. Based on the $r$ values in the rotated component matrix and the created correlation matrix, 10 indicators in total were finally selected for further processing. The following indicators represented the most significant correlation with the components in the rotated components matrix:

- $\quad$ ageing index - number of elderly (above the age of 65) population compared to the young population (below the age of 18);

- death rate per 1,000 inhabitants (in per mille);

- rate of children with (multiple social) disadvantages among persons under age 18 (in percentage);

- activity rate (in percentage);

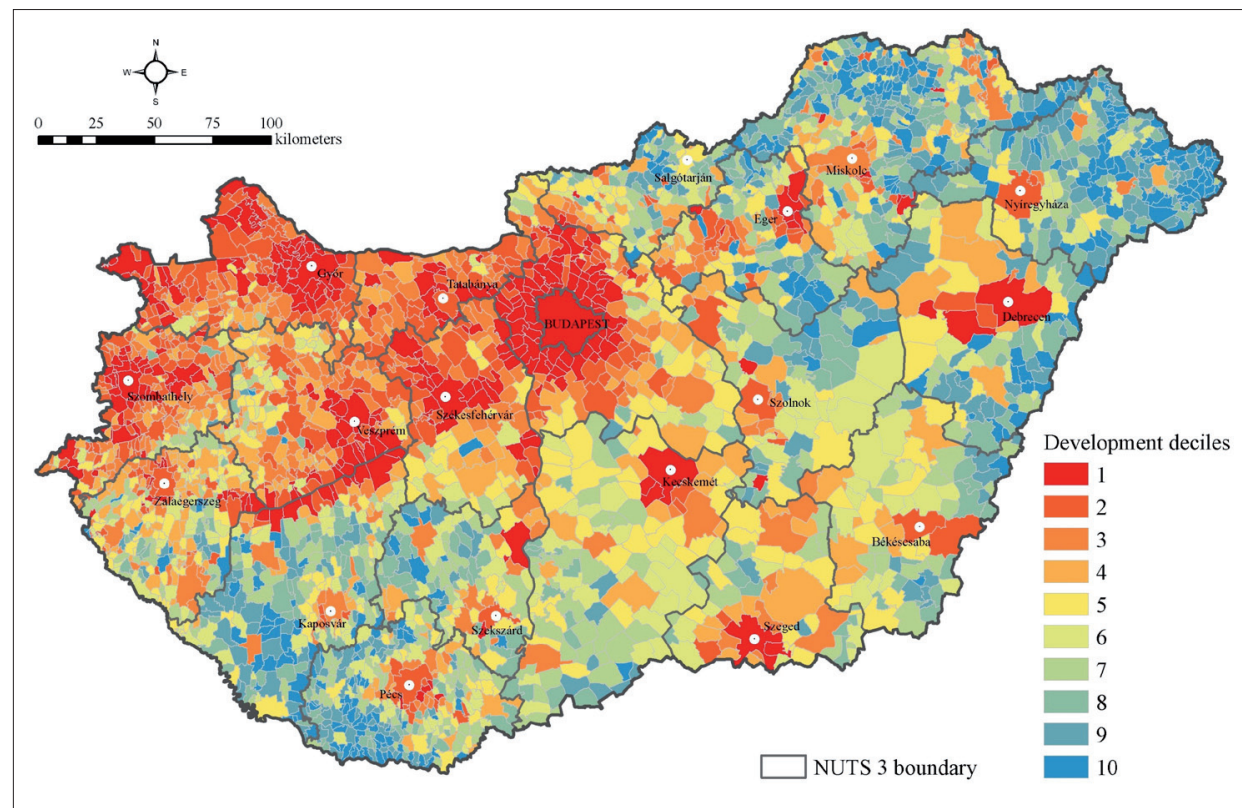

Fig. 1: The development pattern shown by the deciles of the Territorial Development Index of the Hungarian settlements in 2016

Sources: author's elaboration based on the datasets from Hungarian Central Statistical Office and TeIR

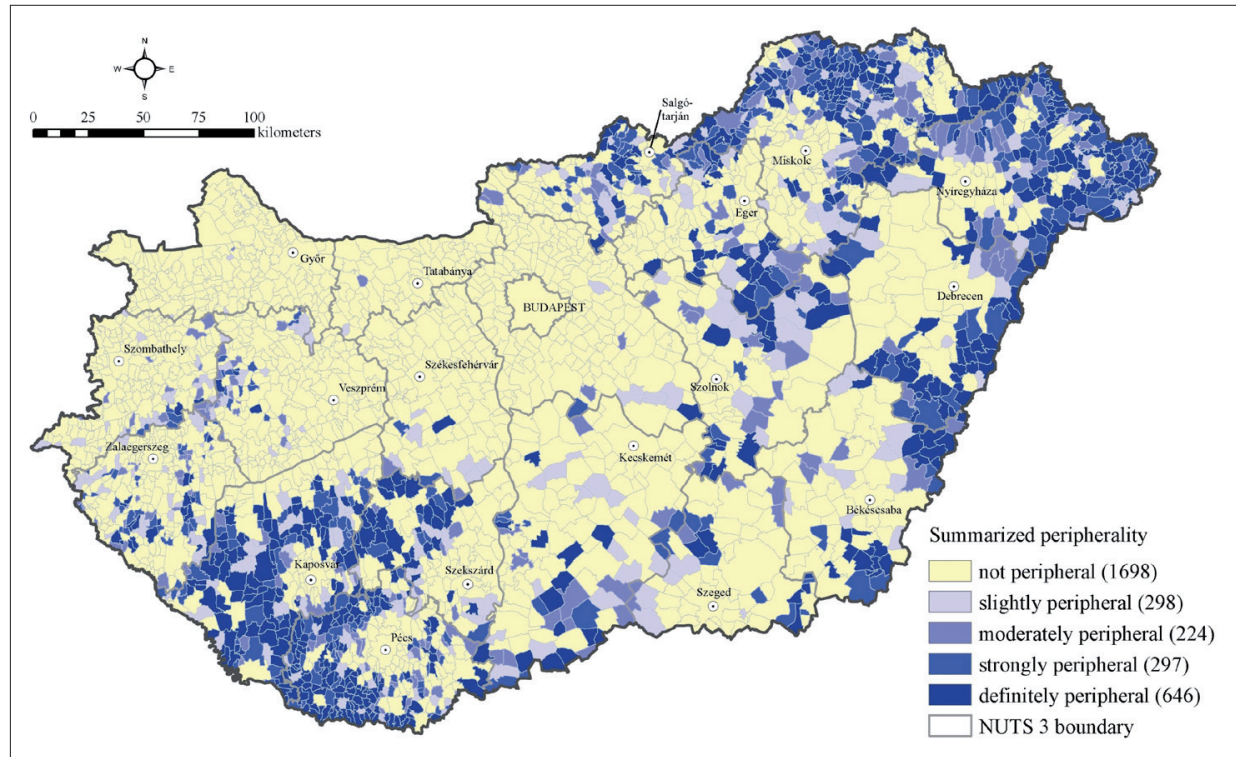

Fig. 2: Summarised pattern of peripherality/backwardness based on the results of four different computations on development level (slightly peripheral: indicated as periphery by one of the methods - definitely peripheral: delimited as periphery by all four methods)

Sources: authors' elaboration based on the datasets from Hungarian Central Statistical Office and TeIR; Koós, 2015; Nagy and Koós, 2014; 105/2015 [23 ${ }^{\text {rd }}$ April] governmental decree of the Hungarian Government 
- ratio of dwellings without comfort (substandard dwellings) (in percentage);

- taxable income per inhabitant (in HUF/capita);

- number of taxpayers per 100 inhabitants (in person);

- registered crimes per 1,000 inhabitants (in pieces);

- number of registered enterprises per 1,000 inhabitants (in pieces); and

- number of broadband internet connections per 100 inhabitants (in pieces).

There were 8 indicators derived from 2016, while the 'activity rate' and the 'ratio of dwellings without comfort' were from 2011 (from the census dataset).

These 10 listed indicators were statistically appropriate to classify peripheral settlements. A hierarchical clustering procedure was applied using the most often-cited Ward method (e.g. Pászto et al., 2019) and squared Euclidean distance measurement by standardised variables.

The resulting clusters were characterised by some of the most important indicators. It is worth pointing out that the proportion or number of Roma population was not part of the set of indicators used for the delineation of peripheral areas. However, the presence of the Roma population is mentioned in the description because of their sharply disparate demographic behaviour influencing most of the indicator values (e.g. health status or mortality) (Rosicova et al., 2009; Nagy et al., 2015; Sárváry et al., 2019) and partly because of the significant overlap between the spatial location of the Roma and the backward areas (Pásztor, 2011; Mušinka et al., 2014; Taylor et al., 2018).

\section{Results}

Hungary's spatial development pattern showed characteristic regional disparities as illustrated by the territorial development index (TDI - computed on the basis of datasets from 2016) (Fig. 1). The values of the TDI-index were ranked into deciles in decreasing order. The results clearly demonstrate the separation of core and peripheral territories within the country. The most characteristic and developed zone was constituted by the agglomeration of Budapest. Extended developed areas were located near the county seats (especially in the north-western Hungary, in the surroundings of Győr, Székesfehérvár, Szombathely, Veszprém). These suburban zones tended to be linked to each other, forming a generally developed region with only island-like peripheral settlements. The neighbouring territory of the Lake Balaton appeared as a continuous, developed belt. County seats in southern and eastern Hungary had limited effect on the development level of their surroundings. Small and medium-sized towns stand isolated (and were unable to increase their surroundings' level of development) within the continuous peripheral zone along the north-eastern, eastern and southwestern border regions (near the eastern Slovakian, Ukrainian, Romanian and Croatian borders), forming the external periphery. The so-called inner periphery in the Eger-Szolnok-Debrecen triangle along the Middle-Tisza territory became even more visible after the political transition.

The stripe of peripheral settlements extended along the state border of Hungary from Nógrád county (westward from Salgótarján) to Békés county (southward from Békéscsaba) through the surroundings of Ózd (between Salgótarján and Miskolc), the Cserehát (northward from Miskolc), Bodrogköz, Bereg, Szatmár, Nyírség (northward and eastward from Nyíregyháza) and Bihar (southward from Debrecen). It is important to emphasise the backwardness of the South-Transdanubian region too (southward from the Lake Balaton, primarily westward from Kaposvár and southward from Pécs). The territory of the inner periphery is clearly visible. Territorially most concentrated (at the same time traditional) socioeconomic peripheries and the deepest backwardness was detected in the Cserehát (north of Miskolc) and Ormánság (Drava River) areas.

These regional-scale disparities had already existed during the socialist era, and they became more visible during the transition period from communism to capitalism. The West-East developmental slope was stressed by the spatial concentration of peripheral areas in northeastern Hungary, while the better position of central Hungary (with Budapest in its core) was contrasted even more by the compact backward zone in southwestern Hungary (NemesNagy, 2006).

The aforementioned four methodologies provided a comprehensive and broad quantitative basis to delineate the set of peripheral settlements after 2010. Despite the difference in methodological tools and sets of indicators, significant overlap could be detected in the spatial patterns. This draw the attention to the 'rigidity' of spatial patterns (Tab. 1). This feature of Hungary became especially visible after the millennium. On the one hand it meant that core and peripheral areas are well discernible on regional scale, and also that changes in the location and pattern of these backward areas are basically negligible in the last decades. On the other hand, backwardness (and the development as well) became multidimensional - as all the indicators describe a similar pattern of development regardless of differences in methods and datasets.

The overlapping of results is clearly demonstrated by Figure 2. Approximately 53.8\% of the Hungarian settlements were not indicated as backward by any of the introduced developmental calculations, whereas more than one fifth of the settlements $(20.6 \%)$ were delimited as peripheral by all (4) methodologies. These settlements could be labelled as "definitely peripheral" in their socioeconomic and infrastructural development because even differing methods confirmed their backwardness. The categories on Figure 2 between these two extremities reflect the numbers of research that classified the settlement as peripheral. The group of "definitely peripheral" Hungarian settlements is primarily in the focus of the current research in the following paragraphs.

The backwardness of the settlements in the categories of peripherality is clearly seen by some of the demonstrative economic indicators (Tab. 2). These indicators tend to represent declining values parallel to the increase of backwardness. In the case of the 'definitely peripheral' category the rate of unemployment is almost three times higher than the Hungarian average, the taxable income per capita hardly reaches half of the national average and real estate prices show an almost fivefold difference. Peripherality is also related to settlement size: increasing development was typical in case of higher average population. The definitely peripheral settlements are usually small villages, with an average population of approximately 800 , which is only one fourth of the Hungarian average (however, the latter includes Budapest, with its more than 1.7 million inhabitants). There were only four settlements with town administrative rank (namely Cigánd, Hajdúhadház, Nagybajom and Nagyecsed) among the definitely peripheral 


\section{Categories}

Rate of

Average population unemployment among Yearly taxable income number of settlements the population with per capita (1,000 HUF) the age 15-64 (\%)
Average prices of real estates (million HUF)

\begin{tabular}{lrrrr}
\hline Not peripheral & $4,946.1$ & 3.33 & $1,142.3$ & 72.90 \\
Slightly peripheral & $1,208.2$ & 6.97 & 784.0 & 733.2 \\
Moderately peripheral & $1,213.0$ & 7.94 & 638.8 & 2.06 \\
Strongly peripheral & 890.6 & 9.24 & 582.3 & 2.11 \\
Definitely peripheral & 795.2 & 11.52 & $\mathbf{1 , 0 7 4 . 3}$ \\
National average & $\mathbf{3 , 1 0 6 . 4}$ & $\mathbf{4 . 1 8}$ & $\mathbf{1 1 . 5 5}$ \\
\hline
\end{tabular}

Tab. 2: The characteristics of settlements in the categories of peripherality in 2016

Sources: authors' computations based on the datasets from Hungarian Central Statistical Office and TeIR

group of settlements (according to the administrative division there were 346 towns in Hungary in 2016) (Bujdosó et al., 2016).

The geographical location of the definitely peripheral settlements was quite concentrated. Almost $20 \%$ of these settlements were located in Borsod-Abaúj-Zemplén (19.5\%) and in Baranya (19.3\%) counties, while Szabolcs-SzatmárBereg (16.1\%) and Somogy (14.6\%) counties accounted for an additional $30 \%$ (4 counties out of the 19 comprise more than $50 \%$ of the backward settlements). As a result of the quite uneven dispersion of settlements, some of the counties are characterised by a high ratio of definitely peripheral settlements compared to the total number of settlements in the county. More than one third of the settlements were in the most backward category in Szabolcs-SzatmárBereg, Baranya, Hajdú-Bihar, Somogy and Borsod-AbaújZemplén counties, and more than $20 \%$ of the settlements in Tolna, Békés and Heves counties were also categorised as peripheral. At the same time, none of the settlements were definitely peripheral in Győr-Moson-Sopron and in Komárom-Esztergom counties, and the ratio was under $1 \%$ in Pest, Fejér and Vas counties too.

The set of peripheral settlements might be segmented by different dimensions as overviewed in this study. As a part of the current investigation, a hierarchical cluster analysis was carried out in order to detect sub-groups within the group of 'definitely peripheral' settlements. This analysis covered 646 settlements (with $5.24 \%$ of the population of Hungary in 2016), and differentiation was done based on the values of the recently listed 10 indicators selected by the principal component analysis. The most appropriate outputs were produced by the 7 clusters division confirmed by the classification results from the predicted group membership of the discriminant analysis ( $81.9 \%$ of original grouped cases were correctly classified). The 7 resulting clusters can be discerned by some recurring characteristic features (see Tabs. 3-6). As cluster 3 and 4 includes only 6-6 settlements, the analysis focused primarily on the 5 larger clusters.

All clusters reflected disadvantageous demographic, socioeconomic and infrastructural features, but some of their characteristic (distinctive) features are highlighted below.

Cluster 1 included 120 settlements with approximately 92,000 inhabitants (Fig. 3). Moderate aging and an above average ratio of Roma population characterised these settlement. Slightly disadvantageous social, educational and employment scenarios, below average economic conditions and moderate levels of infrastructure are suggested by the indicators. The spatial pattern of this cluster was typically dispersed, but higher concentration could be detected in the eastern part of Szabolcs-Szatmár-Bereg county and in the southern part of the Hungarian Great Plain. High abundance of Cluster 1 could be found in northern Somogy, western Tolna and eastern Baranya. The settlements of this cluster located in the Southern Great Plain typically had larger populations with characteristically lower proportions of Roma. This cluster had the oldest building stock among the definitely peripheral settlements.

Cluster 2 was the largest, with 231 settlements containing approximately 230,000 inhabitants. Juvenile age characteristics seemed to be dominant in much of the Roma population. The social, educational and employment situation could be regarded as moderately disadvantageous,

\begin{tabular}{lccc}
\hline Clusters & $\begin{array}{c}\text { Number of } \\
\text { settlements }\end{array}$ & $\begin{array}{c}\text { Total number of } \\
\text { population }\end{array}$ & $\begin{array}{c}\text { Average population } \\
\text { number of settlements }\end{array}$ \\
\hline Cluster 1 & 120 & 92,129 & 767.7 \\
Cluster 2 & 231 & 226,079 & 978.7 \\
Cluster 3 & 6 & 2,069 & 344.8 \\
Cluster 4 & 6 & 1,005 & 167.5 \\
Cluster 5 & 122 & 107,951 & 884.8 \\
Cluster 6 & 48 & 29,072 & 605.7 \\
Cluster 7 & 113 & 55,412 & 490.4 \\
Definitely peripheral settlements & 646 & 513,717 & 795.2 \\
\hline
\end{tabular}

Tab. 3: The characteristics of settlement-types within the group of definitely peripheral settlements Sources: authors' computations based on the datasets from Hungarian Central Statistical Office and TeIR 
and economic conditions below average were accompanied by moderate levels of infrastructure. Most of the settlements could be found in the traditional borderland peripheries (north-eastern and south-western Hungary) and in the vicinity of the 'massive' backward zone of the Cserehát (see Cluster 6). Clusters 3 and 4 included only a limited number of settlements.

Cluster 5 included 122 settlements and almost 110,000 inhabitants. The young age demographics, rapid growth, and high percentage of Roma population could be observed as characteristic. Significantly disadvantageous social, educational and employment situations, below average economic conditions and moderate levels of infrastructure were detected in the case of these settlements. Most of the settlements in this cluster seemed to be located in the former structural crisis areas whose employment problems after the regime change led to complex cumulative social and economic backwardness. The average size of the settlements was almost 900 inhabitants.

Cluster 6 covered settlements with the worst conditions: 48 settlements and almost 30,000 inhabitants were in this cluster. An extremely young demographic structure with

\begin{tabular}{|c|c|c|c|c|c|c|}
\hline Clusters & 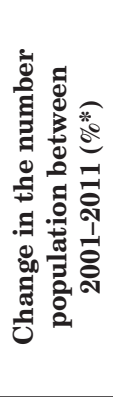 & 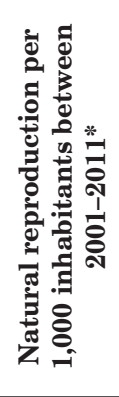 & 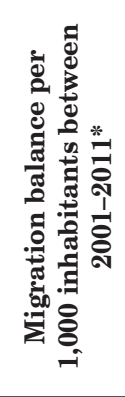 & 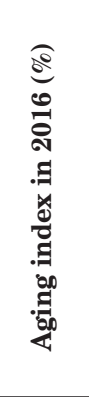 & 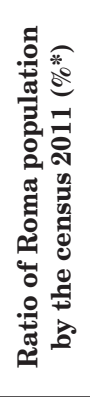 & 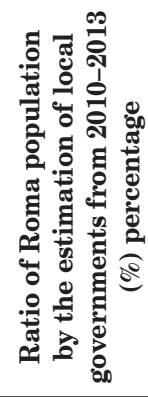 \\
\hline Cluster 1 & -12.1 & -114.5 & -6.9 & 137.0 & 8.8 & 21.3 \\
\hline Cluster 2 & -7.8 & -29.0 & -49.3 & 88.8 & 14.0 & 27.2 \\
\hline Cluster 3 & -13.4 & -10.9 & -123.5 & 77.0 & 19.7 & 43.8 \\
\hline Cluster 4 & -7.9 & -476.7 & 397.2 & 307.4 & 9.4 & 17.2 \\
\hline Cluster 5 & -5.7 & 5.3 & -62.1 & 64.4 & 22.4 & 38.3 \\
\hline Cluster 6 & 0.2 & 89.2 & -87.6 & 30.6 & 44.2 & 64.9 \\
\hline Cluster 7 & -10.3 & -25.6 & -77.8 & 70.4 & 21.2 & 40.2 \\
\hline Definitely peripheral together & -8.0 & -31.8 & -48.6 & 82.7 & 17.2 & 31.9 \\
\hline National average & -2.6 & -39.0 & 12.7 & 128.5 & 3.2 & 8.8 \\
\hline
\end{tabular}

Tab. 4: The demographic characteristics of settlement-types within the group of definitely peripheral settlements in 2016. Sources: authors' computations based on the datasets from Hungarian Central Statistical Office and TeIR *census data from 2011. Below and above average data are indicated by grey background

\begin{tabular}{|c|c|c|c|c|c|c|}
\hline Clusters & 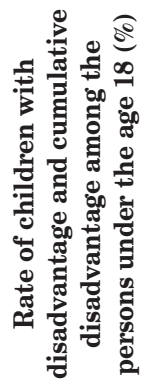 & 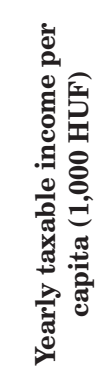 & 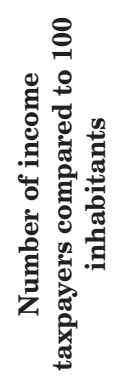 & 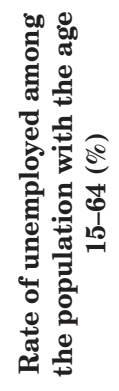 & 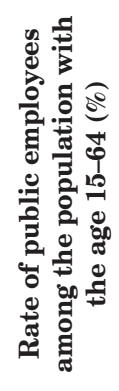 & 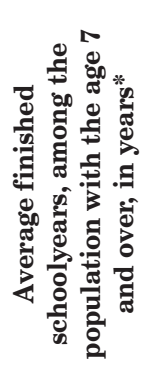 \\
\hline Cluster 1 & 37.9 & 602.5 & 45.1 & 9.2 & 11.9 & 8.97 \\
\hline Cluster 2 & 50.3 & 643.0 & 48.7 & 10.9 & 15.4 & 8.96 \\
\hline Cluster 3 & 58.4 & 575.7 & 48.8 & 10.2 & 22.2 & 9.04 \\
\hline Cluster 4 & 61.9 & 370.7 & 36.6 & 10.2 & 20.6 & 7.95 \\
\hline Cluster 5 & 57.5 & 520.1 & 43.1 & 13.1 & 15.4 & 8.51 \\
\hline Cluster 6 & 78.7 & 373.4 & 39.6 & 16.8 & 25.9 & 7.52 \\
\hline Cluster 7 & 68.5 & 538.8 & 46.9 & 12.3 & 21.8 & 8.51 \\
\hline Definitely peripheral together & 54.9 & 582.3 & 46.1 & 11.5 & 16.1 & 8.75 \\
\hline National average & 12.1 & $1,074.3$ & 49.8 & 4.2 & 3.4 & 10.80 \\
\hline
\end{tabular}

Tab. 5: The income and employment characteristics of settlement-groups within the definitely peripheral settlements in 2016. Sources: authors' computations based on the datasets from Hungarian Central Statistical Office and TeIR *ensus data from 2011. Below and above average data are indicated by grey background 
a high percentage of Roma could be detected. Expressively disadvantageous social, educational and employment conditions characterised this cluster, with poor economic conditions and low levels of infrastructure. A slight population increase was observed as massive migration loss was counterbalanced by a significant natural reproduction rate. The rate of socially challenged children with cumulative disadvantages is extremely high. The settlements in this cluster are dominantly concentrated in the traditional backward area of the Cserehát, northward from Miskolc in northern Hungary and in the edge of Bodrogköz with weak connections. These tendencies drew attention to the formation of a subregion with segregated and marginalised populations (this process could be described as 'territorial ghettoisation') (Virág, 2006).
Cluster 7 included 113 settlements with more than 55,000 inhabitants. The average population size is below 500 inhabitants, thus this cluster contains the group of peripheral small villages. Besides this, the remaining descriptive features were similar to those in Cluster 5. Evidently, a juvenile age demographic structure was accompanied by the high percentage of Roma population. An obvious disadvantageous social and educational situation can be detected here. Dependence on employment (due to the extremely important role of public employment), below average economic conditions and moderate level of infrastructure can also be observed. This type of peripheral settlement was primarily located west of Pécs and northward from Miskolc in the surroundings of the settlements in Cluster 6 (dominated by Roma population).

\begin{tabular}{|c|c|c|c|c|c|c|}
\hline Clusters & 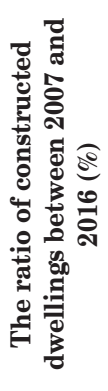 & 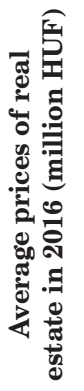 & 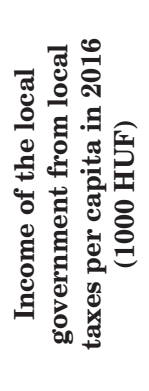 & 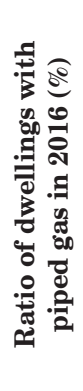 & 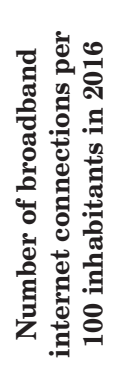 & 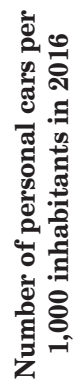 \\
\hline Cluster 1 & 0.52 & 2.17 & 12.75 & 48.5 & 15.61 & 243.1 \\
\hline Cluster 2 & 1.10 & 2.39 & 9.70 & 47.6 & 14.05 & 229.2 \\
\hline Cluster 3 & 2.83 & 2.55 & 2.42 & 47.3 & 10.20 & 241.2 \\
\hline Cluster 4 & 0.92 & 1.38 & 6.99 & 14.2 & 4.28 & 177.1 \\
\hline Cluster 5 & 1.16 & 2.20 & 13.32 & 41.1 & 8.57 & 204.3 \\
\hline Cluster 6 & 1.61 & 1.76 & 4.37 & 22.6 & 6.85 & 130.8 \\
\hline Cluster 7 & 1.07 & 2.00 & 6.49 & 33.1 & 9.41 & 203.6 \\
\hline Definitely peripheral together & 1.02 & 2.23 & 10.32 & 43.8 & 12.24 & 218.0 \\
\hline National average & 4.10 & 11.59 & $\mathbf{5 0 . 8 0}$ & 72.9 & 27.55 & 338.1 \\
\hline
\end{tabular}

Tab. 6: The economic and infrastructural characteristics of settlement-groups within the definitely peripheral settlements in 2016. Sources: authors' computations based on the datasets from Hungarian Central Statistical Office and TeIR. Below and above average data are indicated by grey background

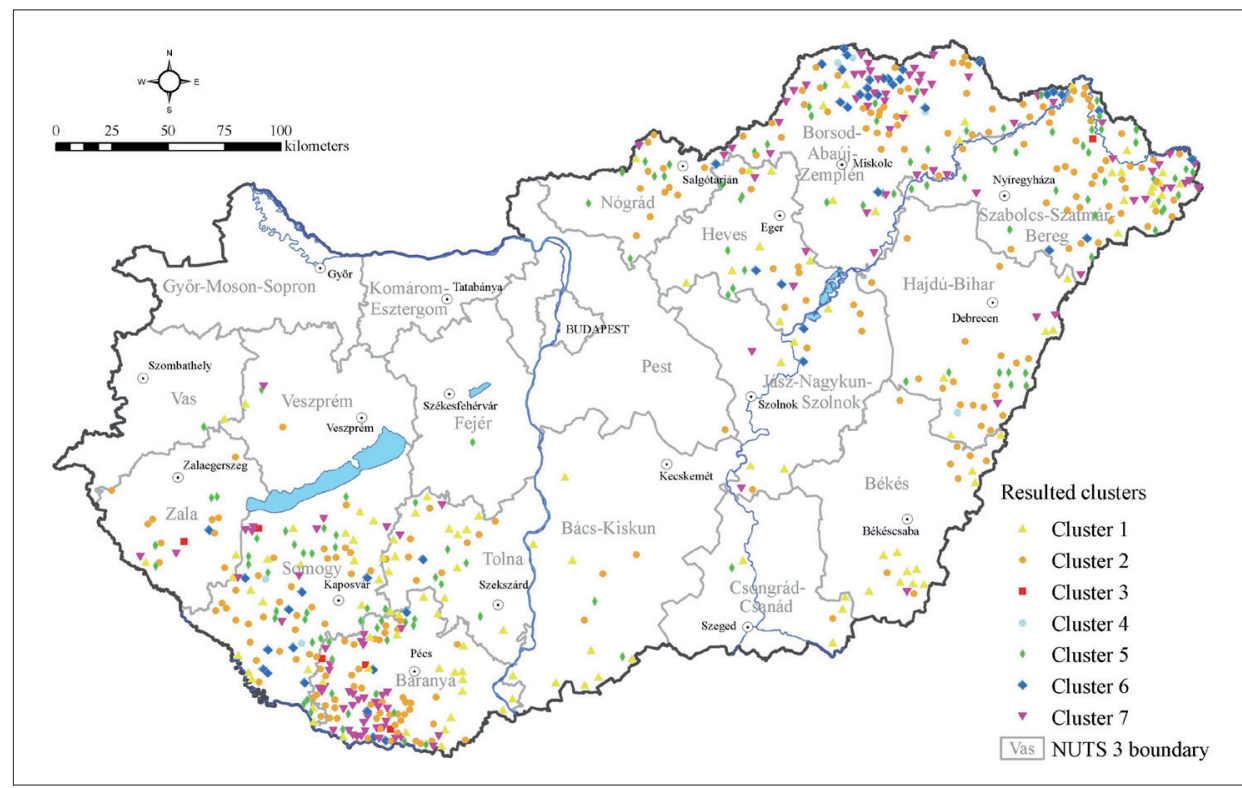

Fig. 3: Types of the definitely peripheral settlements as indicated by the results of the cluster analysis in 2016 Sources: authors' elaboration based on the datasets from Hungarian Central Statistical Office and TeIR 


\section{Discussion}

The results of the comparative analysis drew attention to the spatial pattern of peripheral areas, showing territorial concentration, and to the ongoing processes of spatial marginalisation with several cumulative socioeconomic symptoms. The different approaches to peripherality and marginality (Novotný et al., 2015) significantly overlap each other in the case of the concentrated backward areas along the state border of north-eastern and southwestern Hungary (for this reason, the two phenomena are hard to separate). The pattern and situation of 'definitely peripheral' areas strengthen any scepticism about the chance of polycentric development (Malý, 2016; Mulíček and Malý, 2019), and confirm the ongoing and enduring polarisation at a localised scale (Copus, 2001). The 'rigid' spatial pattern represented only limited alteration in the last decades due to transport investments (Tóth, 2006; Egri and Kőszegi, 2020), and developments financed by the Cohesion Fund of the EU (Kovács and Koós, 2018), because of the impact of the hierarchy of settlements on the financial resource allocation.

The resulting clusters tend to highlight different characteristics and probably different paths or reasons behind their general backwardness and disadvantageous demographic, social, economic and infrastructural situation. The geographical location of the different groups tends to confirm the existence of semi-periphery and the fuzzy-like character of backwardness instead of the dual concept of core-periphery. Both the borderland peripheries and the inner peripheries were inhomogeneous, that is, composed of several different clusters.

The analysis of differences between the clusters of the investigated peripheral settlements might elicit some proposals in support of potential future policy interventions. The main problem to which we want to draw attention, however, is that clusters showing territorial concentration require different treatment from those areas, where peripherality shows a dispersed pattern, or a spatially compact backward zone, composed of settlements belonging to numerous different clusters. The fuzziness and intermingling makes allocation of sources difficult, as well as the dispersed patterns, because the problems of these areas cannot be always resolved by a large investment, but sometimes numerous smaller and well-targetted measures are required in development planning and socio-politics. In short, a differentiated regional planning is required to overcome the problems of peripheral areas in Hungary.

Cluster 1 is regarded as the least backward of all the clusters. The situation in Cluster 2 could be improved by the expansion of education and basic social services, with the controlled intervention of the state specified by local conditions. Clusters 6 and 7 demonstrated the most characteristic spatial concentration in the traditional backward areas in Hungary, while cluster 3 partly represented higher density close to previously mentioned zones. Clusters 1 and 5 were dispersed regarding their spatial pattern. Clusters 5 to 7 reflect disadvantageous demographics with the rapid growth of the marginalised Roma communities (Váradi and Virág, 2014; Pénzes et al., 2019), and selective migration that deepens the unfavourable situation (Michálek and Podolák, 2010; Kubeš and Kraft, 2011; Miszczuk and Wesołowska, 2012; Kebza, 2018). This population growth, especially in the case of the 'definitely peripheral' settlements, caused even an increase in population numbers in some of the settlement groups - in contrast to the findings of Musil and Müller
(2006), Kubeš and Kraft (2011), or Miszczuk and Wesołowska (2012). The situation is exacerbated by the processes of the real estate markets (Pósfai and Nagy, 2017). The worsening condition and aging dwellings in these areas are reflected in the extremely low real estate prices, which - initiating a vicious circle - hinders escape from these backward settlements, whereas low real estate prices attract more and more deprived people.

This paper did not investigate processes of peripheralisation and did not trace the "way to backwardness" - as generally proposed by Kühn (2014) and Lang (2015). Regardless, the developmental paths of peripheral settlements should be investigated in order to discover backwardness factors that became dominant during the last three decades. Previous studies have already highlighted the driving processes and shifts in zones of peripherization (Győri and Mikle, 2017, Demeter, 2018, Demeter, 2020, Papp et al., 2021). We rather stress the urgent need for a more sophisticated, territoriality differentiated approach in regional development planning, as discussed above.

Comprehensive but adaptive state interventions should be implemented to slow down the spatial polarisation and mitigate its socio-economic consequences in Hungary, processes that seem to be very concentrated. The situation is crying for urgent steps that cannot only be solved with European Union tenders (Kovács and Koós, 2018). The most important objective should be to prevent the creation of extended and contiguous / compact groups of settlements with backward features by supporting the emergence of local centres, or by the deconcentration of investments, even if still concentrated in larger towns with better accessibility (parallel to the improvement in basic local infrastructure). Besides respecting the European idea of an integrated territorial approach, regional and local specificities should also be consciously taken into account (Kubeš and Kraft, 2011; Malý and Mulíček, 2016), and new approaches to territorial government should be implemented (Leick and Lang, 2018), including not simply a decentralisation of decision making but a realistic consideration of local demands, possibilities and experience.

\section{Conclusions}

This study has focussed on the delimitation and classification of peripheral settlements with an application of multivariate statistical methods, using the example of Hungary - as a representative country that experienced structural changes both after the collapse of the socialist regime and after the accession to the EU - within one generation. After giving a comprehensive overview of the most important methodologies applied to delimit peripheral settlements in Hungary after 2010, settlements indicated as peripheral by all four analysed methods were considered as 'definitely peripheral', and this group was subject of further examination. The strong spatial correlation and significant overlaps between these methods illustrates the 'rigid' spatial development pattern of Hungary, becoming even more polarised after the millennium. Core and peripheral areas (in varying degrees) show remarkably distinctive spatial (regional) patterns.

More than one fifth of the Hungarian settlements (646 settlements) was regarded as 'definitely peripheral' (being socio-economically peripheral according to all investigations). Initially, 53 different demographic, social, economic and 
infrastructural variables were involved in the investigation to describe and characterise these settlements. Using normality tests and Principal Components Analysis, this number was reduced to the most appropriate 10 indicators, which provided the basic dataset for the application of hierarchical cluster analysis, which grouped the 646 cases into 7 clusters. Five of these groups had special identifiable characteristics that distinguished the groups from one another. The territorial pattern of the clusters did not indicate any sharp boundaries between them as the clusters showed mixed territorial patterns, even though some spatial segregation became visible.

The problems of most peripheral settlements seemed to have a close correlation to the rapid growth and significantly increasing percentage of the Roma population. The poverty and marginalisation with cumulative socioeconomic backwardness is especially concentrated in north-eastern and southwestern Hungary.

Future research should focus on those initiatives and interventions (on the government level [or by its institutional network], on the local governmental level, or on the level of church and civil society - NGOs) that mitigate the problems that were discovered. As our results pointed to the differing characteristics of backward settlements in Hungary, these would require special, territorially adaptive measures and targeted attempts, unique solutions to improve their condition.

\section{Acknowledgement}

„János Pénzes' researches are supported by the ÚNKP-17-4 New National Excellence Program of the Ministry of Human Capacities". Gábor Demeter's research was supported by the MTA BTK Lendület Ten Generations Research Group.

\section{References:}

BAŃSKI, J., DEGÓRSKI, M., KOMORNICKI, T., ŚLESZYŃSKI, P. (2018): The delimitation of areas of strategic intervention in Poland: A methodological trial and its results. Moravian Geographical Reports, 26(2): 84-94.

BARANYI, B. (2004): Gondolatok a perifériaképződés történeti előzményeiről és következményeiről. Tér és Társadalom, 18(2): 1-21.

BELUSZKY, P. (1976): Területi hátrányok a lakosság életkörülményeiben - Hátrányos helyzetű területek Magyarországon. Földrajzi Értesítő, 25(2-4): 301-312.

BELUSZKY, P. (1979): Településformáló folyamatok a falusi térségekben. In: Halay, T. [ed.]: Gazdaság, település és társadalomszerkezet III. (pp. 253-281). Budapest, MSZMP KB Társadalomtudományi Intézete.

BERNARD, J., ŠIMON, M. (2017): Vnitřní periferie v Česku: Multidimenzionalita sociálního vyloučení ve venkovských oblastech. Sociologický časopis/Czech Sociological Review, 53(1): 3-28.

BERNT, M., COLINI, L. (2013): Exclusion, marginalization and peripheralization. Conceptual concerns in the study of inequalities. Working Paper. Erkner, Leibniz Institute for Regional Development and Structural Planning.

BERRY, B. J. L. (1964): Aproaches to regional analysis: A synthesis. Annals of the Association of American Geographers, 54(1): 2-11.
BORGATTI, S. P., EVERETT, M. G. (1999): Models of core/ periphery structures. Social Networks, 21(4): 375-395.

BUJDOSÓ, Z., GYURKÓ, Á., HÁGEN, I. (2016): Socioeconomic aspects of the urbanization in Northern Hungary in the $21^{\text {st }}$ century. Folia Geographica, 58(2): 35-53.

COPUS, A. K. (2001): From core-periphery to polycentric development: Concepts of spatial and aspatial peripherality. European Planning Studies, 9(4): 539-552.

CSATÁRI, B., FARKAS, J.Z. (2008): Agrarian and rural development in Hungary, 1990-2005. In: Bańsky, J., Bednarek, M. [eds.]: Contemporary changes of agriculture in East-Central Europe (pp. 147-164). Warsaw, Polish Academy of Sciences, Institute of Geography and Spatial Organization; Polish Geographical Society.

DEMETER, G. (2018): Területi egyenlőtlenségek, perifériák és funkcionális régiók elkülönítése a történeti Magyarország területén (1890-1910). Történeti Térinformatikai Tanulmányok, 5: 1-71.

DEMETER, G. (2020): Estimating Regional Inequalities in the Carpathian Basin - Historical Origins and Recent Outcomes (1880-2010). Regional Statistics, 10(1): 23-59.

DÖVÉNYI, Z. (2001): Development and spatial disparities of unemployment in Hungary. In: Meusburger, P., Jöns, H. [eds.]: Transformations in Hungary: essays in economy and society (pp. 207-224). New York-Heidelberg, Physica-Verlag.

EGEDY, T. (2017): A külföldre ingázás statisztikai, demográfiai és területi jellemzői Magyarországon. Területi Statisztika, 57(4): 385-405.

EGRI, Z., KŐSZEGI, I. R. (2018): A gazdasági-társadalmi (komplex) térszerkezet kelet-közép-európai képe. Területi Statisztika, 58(1): 27-56.

EGRI, Z., KŐSZEGI, I. R. (2020): A közúti elérhetőség szerepe a kelet-magyarországi gazdasági teljesítményben és gazdaságfejlesztésben. Területi Statisztika, 60(6): 653-687.

ERLEBACH, M., HALÁS, M., DANIEL, J., KLAPKA, P. (2019): Is there congruence in the spatial patterns of regions derived from scalar and vector geographical information? Moravian Geographical Reports 27(1): 2-14.

GAWRYSZEWSKI, A., POTRYKOWSKA, A. (1988): Rural depopulation areas in Poland. Geographia Polonica 54: 81-100.

G. FEKETE, É. (1991): Dinamikus, depressziós és stagnáló területek Borsod-Abaúj-Zemplén megyében 1870-1987 között. Földrajzi értesítő, 40(3-4): 317-332.

GORZELAK, G. (1996): The regional dimension of transformation in Central Europe. Regional Policy and Development 10. London, Regional Studies Association, Jessica Kingsley Publishers.

GYŐRI, R., MIKLE, G. (2017): A fejlettség területi különbségeinek változása Magyarországon, 1910-2011. Tér és társadalom, 31(3): 144-164.

HALÁS, M. (2008): Priestorova polarizacia spoločnosti $\mathrm{s}$ detailnym pohladom na periferne regiony Slovenska. Sociologicky časopis/Czech Sociological Review, 44(2): 349-369.

HALÁS, M. (2014): Modelovanie priestorového usporiadania a dichotómie centrum - periféria. Geografie, 119(4): 384-405. 
HALÁS, M., HURBÁNEK, P. (2008): Identifikácia a klasifikácia periférnych regiónov (pokus o syntézu). In: Džupinová, E. et al. [eds.]: Periférnost́ a priestorová polarizácia na území Slovenska (pp. 109-136). Bratislava, Geo-grafika.

HAVLÍČEK, T., CHROMÝ, P., JANČÁK, V., MARADA, M. (2005): Vybrané teoreticko-metodologické aspekty a trendy geografickeho výzkumu periferních oblastí. In: Novotná, M. [ed.]: Problémy periferních oblastí (pp. 6-24). Praha, Univerzita Karlova v Praze.

HEIDENREICH, M. (2003): Regional Inequalities in the Enlarged Europe. Journal of European Social Policy, 13(4): 313-333.

KEBZA, M. (2018): The development of peripheral areas: The case of West Pomeranian Voivodeship, Poland. Moravian Geographical Reports, 26(1): 69-81.

KISS, J.P. (2012): Hátrányos helyzetű rurális térségek elérhetőségének változásai (1984-2008). In: NemesNagy, J. [ed.]: Térfolyamatok, térkategóriák, térelemzés. Regionális Tudományi Tanulmánok 16 (pp. 61-79). Budapest, ELTE Regionális Tudományi Tanszék.

KISS, J. P., SZALKAI, G. (2014): A foglalkoztatás területi koncentrációjának változásai Magyarországon a népszámlálások ingázási adatai alapján, 1990-2011. Területi Statisztika, 54(5): 415-447.

KOMORNICKI, T., CZAPIEWSKI, K. [eds.] (2006): Europa XXI - 14. Core and peripheral regions in Central and Eastern Europe. Warsaw, Polish Academy of Sciences.

KOÓS, B. (2015): A szegénység és depriváció a magyar településállományban az ezredfordulót követően - avagy kísérlet a települési deprivációs index létrehozására. Tér és Társadalom, 29(1): 53-68.

KOVÁCS, K. (2010): Területi-társadalmi egyenlőtlenségek a rendszerváltozás utáni Magyarországon. In: Fábián, A. [ed.]: Párbeszéd és együttműködés. Területfejlesztési Szabadegyetem 2006-2010 (pp. 15-32). Sopron, NyugatMagyarországi Egyetem Kiadó.

KOVÁCS, K., KOÓS, B. (2018): A település-állomány jólléti pozíciójának mintázatai és azok változása 1990-2016. Észak-magyarországi stratégiai füzetek, 15(3): 13-30.

KOVÁCS, Z. (2004): Socio-economic transition and regional differentiation in Hungary. Geographical Bulletin, 53(1-2): 33-49.

KUBEŠ, J., KRAFT, S. (2011): Periferní oblasti jižních Čech a jejich sociálně populační stabilita. Sociologicky časopis/ Czech Sociological Review, 47(4): 805-829.

KÜHN, M. (2014): Peripheralization: Theoretical Concepts Explaining Socio-Spatial Inequalities. European Planning Studies, 23(2): 367-378.

LANG, T. (2015): Socio-economic and political responses to regional polarisation and socio-spatial peripheralisation in Central and Eastern Europe: a research agenda. Hungarian Geographical Bulletin, 64(3): 171-185.

LEICK, B., LANG, T. (2018): Re-thinking non-core regions: planning strategies and practices beyond growth. European Planning Studies, 26(2): 213-228.

LEIMGRUBER, W. (1994): Marginality and marginal regions: problems of definition. In: Chang Chang-Yi, D. et al. [eds.]: Marginality and Development Issues in Marginal Regions (pp. 1-18). Taipei, IGU-National Taiwan University.
LEIMGRUBER, W. (2007): Geographical marginality - past and new challenges. In: Jones, G. et al. [eds.]: Issues in Geographical Marginality - General and theoretical aspects (pp. 3-12). Grahamstown, South Africa, IGURhodes University.

LŐCSEI, H., SZALKAI, G. (2008): Helyzeti és fejlettségi centrum-periféria relációk a hazai kistérségekben. Területi Statisztika, 48(3): 305-314.

MALÝ, J. (2016): Impact of Polycentric Urban Systems on Intra-regional Disparities: A Micro-regional Approach. European Planning Studies, 24(1): 116-138.

MALÝ, J., MULÍČEK, O. (2016): European territorial cohesion policies: Parallels to socialist central planning? Moravian Geographical Report, 24(1): 14-26.

MICHÁLEK, A., PODOLÁK, P. (2010): Socio-economic disparities and migration in Slovakia. Moravian Geographical Report, 18(2): 36-45.

MISZCZUK, A., WESOŁOWSKA, M. (2012). Demographic and settlement transformations in peripheral regions (based on the example of eastern Poland). Annales UMCS, Geographia, Geologia, Mineralogia et Petrographia, 67(1): 141-151.

MOLNÁR, E., KOZMA, G., MÉSZÁROS, M., KISS, É. (2020): Upgrading and the geography of the Hungarian automotive industry in the context of the fourth industrial revolution. Hungarian Geographical Bulletin, 69(2): 137-155.

MULÍČEK, O., MALÝ, J. (2019): Moving towards more cohesive and polycentric spatial patterns? Evidence from the Czech Republic. Papers in Regional Science, 98(2): 1177-1194.

MUSIL, J., MÜLLER, J. (2006): Vnitřní periferie České republiky, sociální soudržnost a sociální vyloučení. Praha, CESES FSV UK.

MUŠINKA, A., ŠKOBLA, D., HURRLE, J., MATLOVIČOVÁ, K., KLING, J. (2014): Atlas rómskych komunít na Slovensku 2013. Bratislava, UNDP.

NAGY, A. (2009): A hazai területfejlesztés eddigi történetéből: A hazai területfejlesztési források felhasználásának tapasztalatai. Falu Város Régió, 16(3): 54-61.

NAGY, E., TIMÁR, J., NAGY, G. (2012): The changing meaning of core-periphery relations of a non-metropolitan "urban region" at the Hungarian-Romanian border. DISP - The Planning Review, 48(2): 93-105.

NAGY, E., TIMÁR, J., NAGY, G., VELKEY, G. (2015): The everyday practices of the reproduction of peripherality and marginality in Hungary. In: Lang, T., Henn, S., Sgibnev, W., Ehrlich, K. [eds.]: Understanding geographies of polarization and peripheralization: perspectives from Central and Eastern Europe and beyond (pp. 135-155). London, Palgrave MacMillan.

NAGY, G., KOÓS, B. (2014): First results in modelling objective well-being in Hungary at lower territorial level. Regional Statistics, 4(2): 71-86.

NEMES-NAGY， J. (1996): Centrumok és perifériák a piacgazdasági átmenetben. Földrajzi Közlemények, 120(1): 31-48.

NEMES NAGY, J. (2000): Regional inequalities in Hungary at the end of the socio-economic transition. In: Kovács, Z. [ed.]: Hungary towards the $21^{\text {st }}$ century - the 
human geography of transition (pp. 87-98). Budapest, Geographical Research Institute, Hungarian Academy of Sciences.

NEMES-NAGY, J. (2006): Regional inequalities: general models and the case of the transition countries. Romanian Review of Regional Studies, 2(1): 23-34.

NOVOTNÝ, L., MAZUR, M., EGEDY, T. (2015): Definition and delimitation of peripheries of Visegrad countries. Studia Obszarów Wiejskich, 39: 35-48.

PAPP, I., PÉNZES, J., DEMETER, G. (2021): A közlekedési hálózatok és a komplex területi fejlettség időbeli összehasonlító vizsgálatának nehézségei és egy megoldási lehetősége a történelmi Magyarország példáján. Területi Statisztika, in press.

PAPP, S., NAGY, G., BOROS, L. (2017): A kedvezményezett települések objektív életminőség alapján történő lehatárolási lehetőségei. Területi Statisztika, 57(6): 639-664.

PÁSZTO, V., MACKŮ, K., BURIAN, J., PÁNEK, J., TUČEK, P. (2019): Capturing cross-border continuity: The case of the Czech-Polish borderland. Moravian Geographical Reports, 27(2): 122-138.

PÁSZTOR, I. Z. (2011): Location of the gypsies in the Northern Great Plain and North Hungary Regions. In: Kozma, G. [ed.]: New Results of Cross-Border CoOperation (pp. 151-160). Debrecen, Didakt Kiadó.

PÉNZES, J. (2013a): A foglalkoztatottság, az ingázás és a jövedelmi szint összefüggései Északkelet- és Északnyugat-Magyarországon. Területi Statisztika, 53(3): 202-224.

PÉNZES, J. (2013b): The dimensions of peripheral areas and their restructuring in Central Europe. Hungarian Geographical Bulletin, 62(4): 373-386.

PÉNZES, J. (2015): A kedvezményezett térségek lehatárolásának aktuális kérdései. Területi Statisztika 55(3): 206-232.

PÉNZES, J. (2020): The impact of the Trianon Peace Treaty on the border zones - an attempt to analyse the historic territorial development pattern and its changes in Hungary. Regional Statistics, 10(1): 60-81.

PÉNZES, J., BUJDOSÓ, Z., DÁVID, L., RADICS, Z., KOZMA, G. (2014): Differing development paths of spatial income inequalities after the political transition by the example of Hungary and its regions. Economy of Region, 33(1): 73-84.

PÉNZES, J., PÁLÓCZI, G. (2017): Comparative research of the results of functional regionalization methods - by the network of commuting in Hungary. DETUROPE, 9(3): 29-41.

PÉNZES, J., PÁSZTOR, I. Z., TÁTRAI, P., KÓTI, T. (2019): Roma population in Hungary - spatial distribution and its temporal changes. DETUROPE, 11(3): 138-159.

PERCZEL, K., GERLE, G. (1966): Regionális tervezés és a magyar településhálózat. Budapest, Akadémiai Kiadó.

PÓSFAI, Z., NAGY, G. (2017): Crisis and the Reproduction of Core-Periphery Relations on the Hungarian Housing Market. European Spatial Research and Policy, 24(2): 17-38.

POTRYKOWSKA, A. (1985): Spatial structure of functional urban regions in Poland. Geographia Polonica 51: 113-126.
RAMÍREZ, B. (2009): Core-Periphery Models. In: Kitchin, R., Thrift, N. [eds.]: International Encyclopedia of Human Geography (pp. 286-291). Amsterdam-Oxford, Elsevier.

RECHNITZER, J. (1993): Innovations and regional policy. In: Hajdú, Z. [ed.]: Hungary: Society, State, Economy and Regional Structure (pp. 221-244). Pécs, Hungarian Academy of Sciences, Centre for Regional Studies.

ROSICOVA, K., GECKOVA, A. M., VAN DIJK, J. P., ROSIC, M., ZEZULA, I., GROOTHOFF, J.W. (2009): Socioeconomic indicators and ethnicity as determinants of regional mortality rates in Slovakia. International Journal of Public Health, 54(4): 274-282.

SÁRVÁRY, A., KÓSA, Z., JÁVORNÉ ERDEI, R., GYULAI, A., TAKÁCS, P., SÁNDOR, J., SÁRVÁRY, A., NÉMETH, Á., HALMAI, R., ÁDÁNY, R. (2019): Socioeconomic status, health related behaviour, and self-rated health of children living in Roma settlements in Hungary. Central European Journal of Public Health, 27(1): 24-31.

ŠIMON, M. (2017): Multi-scalar geographies of polarisation and peripheralisation: A case study of Czechia. In: Środa-Murawska, S., Szymańska, D. [eds.]: Bulletin of Geography. Socio-economic Series, No. 37, (pp. 125-137). Torun, Nicolaus Copernicus University.

SOKOL, M. (2001): Central and Eastern Europe a decade after the fall of state socialism: regional dimensions of transition processes. Regional Studies, 35(7): 645-655.

STIEGLITZ, J. E., SEN, A., FITOUSSI, J. P. (2009): Report by the Commission on the Measurement of Economic Performance and Social Progress [online]. Availabale at: http://www.stiglitz-sen-fitoussi.fr/documents/rapport anglais.pdf

SÜLI-ZAKAR, I. (1992): A study of state borders as factors blocking socio-economic progress in North-Eastern Hungary. Földrajzi Közlemények International Edition, 40: 53-63.

SÜTŐ, A. (2008): Város és vidéke rendszerek és típusaik Magyarországon. Falu Város Régió, 15(3): 51-64.

SZABÓ, P. (2003): Regional development disparities in the European Union. In: Jakobi, Á. [ed.]: Frontiers of Geography (pp. 109-119). Budapest-Heidelberg, Eötvös Loránd University.

SZABÓ, T., SZABÓ, B., KOVÁCS, Z. (2014): Polycentric urban development in post-socialist context: the case of the Budapest Metropolitan Region. Hungarian Geographical Bulletin, 63(3): 287-301.

SZILÁGYI, Z. (2019): Regional Differences in Development and Quality of Life in Hungary during the First Third of the Twentieth Century. Hungarian Historical Review, 8(1): 121-152.

TAGAI, G., BERNARD, J., ŠIMON, M., KOÓS, B. (2018): Two faces of peripherality: labour markets, poverty, and population dynamics in Hungary and Czechia. Regional Statistics, 8(2): 19-45.

TAYLOR, A., TÁTRAI, P., ERŐSS, Á. (2018): Visible minorities in remote areas: A comparative study of Roma in Hungary and indigenous people in Australia. Hungarian Geographical Bulletin, 67(1): 43-60.

TIMÁR, J. (2007): Different Scales of Uneven Development in a (No Longer) Post-socialist Hungary. Treballs de la Societat Catalana de Geografia, 64: 103-128. 
TOMCSÁNYI, M. (1986): A gazdaságilag elmaradott térségek néhány sajátos területrendezési és területfejlesztési kérdése. Településfejlesztés, 6(4): 15-18.

TÓTH, G. (2006): Centre-Periphery Analysis about the Hungarian Public Road System. Paper presented at the $46^{\text {th }}$ Congress of the European Regional Science Association, Volos, Greece, 30 August-3 September 2006.

VÁRADI, M. M., VIRÁG, T. (2014): Faces and Causes of Roma Marginalization: Experiences from Hungary. In: Szalai, J., Zentai, V. [eds.]: Faces and Causes of Roma Marginalization in Local Contexts: Hungary, Romania, Serbia (pp. 35-66). Budapest, Central European University.

VIRÁG, T. (2006): The regional ghetto. Review of Sociology of the Hungarian Sociological Association, 12(1): 51-70.
WALLERSTEIN, I. (1976): The Modern World System: Capitalist Agriculture and the Origins of European World Economy. Cambridge, Cambridge University Press.

WILLIAMSON, J. G. (1965): Regional Inequality and the Process of National Development: A Description of the Patterns. Economic Development and Cultural Change, 13(4, Part II): 1-84.

105/2015 [23 ${ }^{\text {rd }}$ April] governmental decree of the Hungarian Government - about the delineation of favoured settlements and its conditionality.

\section{Please cite this article as:}

PÉNZES, J., DEMETER, G. (2021): Peripheral areas and their distinctive characteristics: The case of Hungary. Moravian Geographical Reports, 29(3): 217-230. doi: https://doi.org/10.2478/mgr-2021-0016 